\title{
Melih Cevdet Anday'ın Mikado'nun Çöpleri Oyununda Anlatı Yapısı: Binbir Gece Masalları ve Hikâye Anlatıcılığı
}

\author{
One Thousand and One Nights and Storytelling: Narrative \\ Structure in Melih Cevdet Anday's Play Mikado'nun Çöpleri
}

\author{
Bahar YILDIRIM SAĞLAM ${ }^{1}$ (])
}

DOI: $10.26650 / C O N S 2021-995783$

${ }^{1}$ Dr, İstanbul Üniversitesi, Türkiyat Araştırmaları Doktora Programı, İstanbul, Türkiye

ORCID: B.Y.S. 0000-0002-3179-9498

Sorumlu yazar/Corresponding author: Bahar YILDIRIM SAĞLAM,

İstanbul Üniversitesi, Türkiyat Araştırmaları Doktora Programı, İstanbul, Türkiye

E-posta/E-mail: bhr_yldrm@hotmail.com

Başvuru/Submitted: 15.09.2021

Illk Revizyon/Revision Requested: 29.11.2021

Son Revizyon/Last Revision Requested: 01.12.2021

Kabul/Accepted: 01.12 .2021

Online Yayın/Published Online: 09.12.2021

Atıf/Citation: Yildirim Saglam, B. (2021). Melih Cevdet Anday'ın Mikado'nun Çöpleri oyununda anlatı yapısı: Binbir gece masalları ve hikâye anlatıcılığı. Konservatoryum Conservatorium, 8(2), 223-251. https://doi.org/10.26650/CONS2021-995783 öz

Binbir Gece Masalları'nda Şehrazad, Şehriyar'a bin bir gece boyunca hikâye anlatır. Hikâye anlatıcılığı Şehrazad ile Şehriyar arasındaki bir oyundur. Şehrazad hikâye anlattığı her gece bir gün daha yaşama hakkı elde eder. Melih Cevdet Anday'ın Mikado'nun Çöpleri oyununda da hikâye anlatıcılığı Şehrazad ve Şehriyar arasındaki gibi bir oyuna dönüşür. Bir kış gecesi bir araya gelen Erkek ve Kadın kendilerini birbirlerine sırayla hikâye anlattıkları bir oyunun içinde bulur. Mikado'nun Çöpleri'nde hikâye anlatma arzusu ile hikâyeyi yıkma arzusu bir arada ilerler. Anlatıcı ile dinleyici arasındaki alışveriş kesintiye uğrar. Erkek ve Kadın birbirine gerçek mi yalan mı olduğu belli olmayan hikâyeler anlatır. Mikado'nun Çöpleri oyununda hikâyeler olasılıklara dönüşür, belirsizleşir. Erkek ve Kadın anlatılan hikâyeleri şüphe ile dinler. Oyun hikâye anlatıcılığı geleneğini yapısöküme uğratır. Anlatma eylemini alaya alır. Hikâyeleri anlamsız, içi boşalmış harflere, göstergelere dönüştürür. Oyunda hikâyeleri dinlememe, merakla dinlemeye dönüşür. Anlatıcı anlatmanın hazzını yaşar. Anlatıyı aniden keser, dinleyicisini bekletir; onu etkilemeye, şaşırtmaya, heyecanlandırmaya çalışır. Hikâyeler; yalanla, hileyle, alayla örülür. Bu bağ sebebiyle Melih Cevdet Anday'ın Mikado'nun Çöpleri oyununda anlatının yapısı, Binbir Gece Masalları ve hikâye anlatıcılığı çerçevesinde incelenecektir. Makalede Binbir Gece Masalları ve hikâye anlatıcılığı üzerinde durulacak ardından Melih Cevdet Anday'ın Mikadónun Çöpleri oyununda Binbir Gece Masalları ve hikâye anlatıcılığının nasıl dönüştürüldüğü irdelenecektir.

Anahtar Kelimeler: Binbir Gece Masalları, Mikado'nun Çöpleri, hikâye anlatıcılığı, tiyatro, oyun

\section{ABSTRACT}

In One Thousand and One Nights, Scheherazade tells Shahryar stories for a thousand and one nights. Storytelling is a game between Scheherazade and Shahryar. Every night she tells a story, Scheherazade gets the right to live one more day. In Melih Cevdet Anday's play Mikado'nun Çöpleri, storytelling is turned into a game like that between Scheherazade and Shahryar. Getting together on a winter night, Man and Woman find themselves involved in a game in which they tell each other one story after another. The desire to tell a 
story goes hand in hand with the desire to destroy the story in Mikado'nun Çöpleri. The exchange between the narrator and the listener is interrupted. The Man and the Woman tell each other stories that are not known to be true or false. In the play, stories turn into possibilities and become ambiguous. They reveal suspicion. The Man and the Woman listen to the stories with doubt. The play deconstructs the tradition of storytelling. It mocks the act of narration. It turns stories into meaningless, hollow letters and signs. In Mikado'nun Çöpleri, not listening to the stories turns into listening with curiosity. The narrator experiences the pleasure of telling. He suddenly interrupts the narrative, makes his audience wait, and tries to influence, surprise, and excite the audience. In the play, the stories are woven together with lies, deceit, and sarcasm. Due to this correlate, this paper examines the narrative structure in Anday's Mikado'nun Çöpleri within the framework of One Thousand and One Nights and storytelling. One Thousand and One Nights and the subject of storytelling are discussed, followed by an investigation of how Anday's play Mikado'nun Çöpleri transforms One Thousand and One Nights and storytelling.

Keywords: One Thousand and One Nights, Mikado'nun Çöpleri, storytelling, theater, play

\section{EXTENDED ABSTRACT}

In One Thousand and One Nights, Scheherazade tells Shahryar stories for a thousand and one nights. Storytelling is a game between Scheherazade and Shahryar. Every night she tells a story, Scheherazade gets the right to live one more day. She carries the wisdom of a storyteller. She promises her audience a better story for the next night. She plays games with the narrative, pauses the story at the most exciting moment, surprises, and makes her audience wonder. With the first light of day, she delays her storytelling until the next night. In Melih Cevdet Anday's play Mikado'nun Çöpleri, storytelling is turned into a game like that between Scheherazade and Shahryar. Getting together on a winter night, Man and Woman find themselves involved a game in which they tell each other one story after another. The desire to tell a story goes hand in hand with the desire to destroy the story in Mikado'nun Çöpleri. The exchange between the narrator and the listener is interrupted: the Woman wants to tell; the Man does not listen. The Man tells a story; the Woman tells another story at the same time. Narrator and listener cannot communicate. The Man and the Woman tell each other stories that are not known to be true or false. Due to this correlate, the narrative structure in Anday's Mikado'nun Çöpleri is examined within the framework of One Thousand and One Nights and storytelling. In this paper, One Thousand and One Nights and the subject of storytelling are discussed, followed by an investigation of how Anday's play transforms One Thousand and One Nights and storytelling. The stories told in turns in Anday's Mikado'nun Çöpleri become absurd. They are cut through with sarcasm and irony. They are both told and not told. In Mikado'nun Çöpleri, the stories change directions, take on other disguises. They lose their reality and turn into fabricated narratives. Storytelling in Mikado'nun Çöpleri makes the audience question what the truth is. It emphasizes that we can never reach definitive narratives. In Mikado'nun Çöpleri, stories turn into possibilities and become 
ambiguous. They reveal suspicion. The Man and the Woman listen to the stories with doubt. The play deconstructs the tradition of storytelling. It mocks the act of narration. It turns stories into meaningless, hollow letters and signs. Mikado'nun Çöpleri dissolves the tradition of storytelling in the life of the alienated individual, while at the same time continuing this tradition. In the play, Anday questions the meaning of storytelling. He emphasizes the connection that storytelling establishes between the narrator and the listener. He shows that modern man has broken this bond. In Anday's play, the stories reveal identity, the past, and memory. Stories are clues to getting to know the narrator. The Man and the Woman dissolve each other as they tell stories; the more they tell a story, the more they recover. Storytelling is also a process of construction. The Man and the Woman rebuild the past by remembering it. Then they demolish the building they have built. The stories told by the Man and the Woman ironize the social structure, order, and management system. They show the cracks and absurdities of the system. These stories reveal the contradictions within the individual who becomes alienated as they try to exist in modern society. It reaches a point where everything is meaningless. In the play, not listening to the stories turns into listening with curiosity. The narrator experiences the pleasure of telling. He suddenly interrupts the narrative, makes his audience wait, and tries to influence, surprise, and excite the audience. As Anday presents storytelling, the stories are woven together with lies, deceit, and sarcasm. 


\section{Giriş}

Binbir Gece Masalları'nda Şehrazad, Şehriyar'a bin bir gece boyunca hikâye anlatır. Hikâye anlatıcılığı Şehrazad ile Şehriyar arasındaki bir oyundur. Şehrazad hikâye anlattığı her gece bir gün daha yaşama hakkı elde eder. O, hikâye anlatıcısının bilgeliğini taşır. Dinleyicisine her gece bir önceki geceden daha güzel bir hikâye vadeder. Anlatıyla oyun oynar, hikâyeyi en heyecanlı yerinde keser, dinleyicisini şaşırtır, merak ettirir. Günün ilk 1şıklarıyla anlatıyı bir sonraki geceye erteler.

Melih Cevdet Anday'ın Mikado'nun Çöpleri oyununda da hikâye anlatıcıllğ̆ Şehrazad ve Şehriyar arasındaki gibi bir oyuna dönüşür. Bir kış gecesi bir araya gelen Erkek ve Kadın kendilerini birbirlerine sırayla hikâye anlattıkları bir oyunun içinde bulur. Mikado'nun Çöpleri'nde hikâye anlatma arzusu ile hikâyeyi yıkma arzusu bir arada ilerler. Anlatıcı ile dinleyici arasındaki iletişim kesintiye uğrar. Kadın anlatmak ister, Erkek dinlemez. Aynı anda Erkek başka bir hikâye anlatır, Kadın başka bir hikâye anlatır.

Erkek ve Kadın birbirine gerçek mi yalan mı olduğu belli olmayan hikâyeler anlatır. Hikâyeler bir sonraki hikâyeyi doğurur, giderek çoğalır. Bu bağ sebebiyle Melih Cevdet Anday'ın Mikado'nun Çöpleri oyununda anlatının yapısı, Binbir Gece Masalları ve hikâye anlatıc1lığ 1 çerçevesinde incelenecektir. Makalede Binbir Gece Masalları ve hikâye anlatıcıllğı üzerinde durulacak ardından Melih Cevdet Anday'ın Mikado'nun Çöpleri oyununda Binbir Gece Masalları ve hikâye anlatıcılığının nasıl dönüştürüldüğü irdelenecektir.

\section{Binbir Gece Masalları ve Hikâye Anlatıcılı̆̆ı}

Walter Benjamin Rus hikâye anlatıcısı Nikolay Leskov üzerine yazdığı "Der Erzähler" (Hikâye Anlatıcısı) adlı yazısında "İlk gerçek hikâye anlatıcısı masal anlatıcısıdır". (Benjamin, 2014, s. 94) der. Hikâyeler masalın süzgecinden geçirilerek günümüze taş1nır. En ünlü hikâye anlatıcılarından biri ise Şehrazad'dır.

Peki, Şehrazad ne anlatır? Şehriyar onu nasıl dinler? Anlatıcı ile dinleyici arasındaki ilişki bir çeşit anlaşmaya mı dayanır? Hikâyeler anlatıcısı ve dinleyicisine ne kazandırır? Hikâye anlatıcısı ve dinleyicisi kimdir? Hikâye anlatma nasıl bir arzunun ocağından fışkırır ve dinleme ne zaman başlar? 
Şehrazad hayatını kurtarmak için hikâye anlatır. Bu aynı zamanda eski bir savaş hilesidir. Masallar'ın içindeki pek çok hikâyede aynı kurtuluş tekniği tekrar eder. Üç şeyh, bir tacirin hayatını birbiri ardına üç muhteşem hikâye anlatarak kurtarır:

Bu sözde 'kefaret hikâyeleri' kişinin kendi hayatını ya da bir başkasının hayatını kurtarmak için hikâye anlattığı belirli bir çeşit anlatımı ifade eder. Edebi tarihçi Tsvetan Todorov, bahsedilen özelliği Masallar'ın tipik bir özelliği olarak nitelemiştir ki burada anlatım hayatı kasteder ve sadece nasıl hikâye anlatılacağını bilenler yaşamayı hak ederler (Marzolph, 2010, s. 21).

Binbir Gece Masalları'nda öyküler herhangi bir eylemin tamamlanmasını geciktirmek için anlatılır. Şehrazad anlattığı masallarla öldürülme anını geciktirir. Masallar'da kurnazlığa dayalı öykülerin eksiksiz mekanizmasını görürüz. Ali Baba ve Kırk Haramiler Öyküsü'nde kahraman, evinin tebeşirle işaretlendiğini fark edince etraftaki bütün evleri aynı şekilde işaretler. Bulduğu çözümle ev ahalisini ve kendisini güç durumdan, ölümden kurtarır (Şklovski, 2016, s. 182).

Masallar oyunlarla ve deneyimin bilgeliğiyle örülür: "Bütün hikâye anlatıcılarının beslendiği kaynak, ağızdan ağza aktarılan deneyimdir. (...) Bir atasözü 'Yolculuğa çıkanın anlatacakları vardır,' der; demek ki halkın gözünde hikâye anlatıcısı uzaklardan gelen biridir"' (Benjamin, 2014, s. 78). Benjamin "Hikâye Anlatıcısı"nda anlatıcının, hikâyesini anlatırken onları eğirip dokuyan birine ihtiyaç duyduğunu söyler. Dinleyicinin anlatıyı yeniden inşa ettiğini ve hikâyenin anlatıcı ile dinleyicinin ortak örgüsü olduğunu dile getirir. Günümüzde ise bu örgünün artık söküldüğünü, hikâye dinlerken onları eğirip dokuyan birilerinin kalmadığını ortaya döker (Benjamin, 2014, s. 84). Peki, hikâyeler nasıl sökülür?

Penelope, Laertes'in kefenini dokuyup sökerken kendi elleriyle arzuyu yaratıp yok eder (Baudrillard, 2001, s. 109). Kendi öyküsünü tekrar tekrar yaratır. Roland Barthes $S / Z$ 'de "Anlatının kökeninde arzu vardır" (Barthes, 2016, s. 95) der. Hikâye anlatıcısı hikâye anlatma arzusu ile doludur. Şehrazad bu arzu ile anlatır. Bu arzu ile Binbir Gece'nin sonsuz gecelerine ilmik atar. Sindbad hikâye anlatma arzusu ile denizler arasında yedi yolculuk yapar: "Ey hamal, bil ki benim de bir öyküm var; hem de pek şaşırtıcı. Yaşadığım bütün serüvenleri (...) sana anlatacağım” (Onaran, 2015, s. 242).

Peter Brooks Psikanaliz ve Hikâye Anlatıcılığı'nda anlatıların çoğunun anlatıcının olduğu kadar dinleyicinin de hikâyesi olma arzularını dile getirdiklerini söyler. Dinleyici 
hikâyeyi dinlerken anlatııının bıraktığı boşlukları doldurur, parçaları tutarlı bir bütün oluşturacak biçimde bir araya getirir, hikâyeyi yeniden inşa eder. Anlatıcının dinleyici ile ilişkisi hem işbirliğine hem de mücadeleye dayanır. Anlatıcı hikâyeyi en heyecanlı yerinde keser, daha fazlasını anlatmayı reddeder. Dinleyici de hikâyeye kulak verirken belli bir kuşkuyu elden bırakmaz (Brooks, 2014, s. 74).

Hikâye anlatma baştan çıkarmayla da ilişkilidir. Othello'da ana kahraman, Venedikli bir senatörün kızı olan Desdemona'nın ilgisini çekebilmek için hikâyelere başvurur. Bir hikâye anlatmak kur yapmanın parçasıdır. Şehrazad ve Sindbad'da olduğu gibi, hikâye anlatma ya baştan çıkarır ya da baştan çıkarmaktan kaçınır. Jack Goody Mit, Ritüel ve Söz'de anlatı kelimesinin ikonikleştiğini ve içinin boşaltıldığını söyler (Goody, 2017, s. 180-181).

Benjamin de "Hikâye Anlatıcısı"nda ağızdan ağza aktarılan deneyimin değer kaybettiğinden söz eder ve hikâye anlatıcısının artık hayatımızda hiçbir hükmü olmadığını dile getirir. Ona göre hikâye anlatma sanatı, bilgelik yani hakikatin destansı boyutu öldüğü için ortadan kalkar. Günümüzde uzaklardan gelen bilgi değil, bizi en yakında olup bitene ulaştıran enformasyon kabul görmektedir (Benjamin, 2014, s. 80).

Benjamin; minyatürleri, ince ince işlenen fildişi oymaları örnek göstererek bir zamanlar insanın doğanın sabırlı sürecini taklit ettiğini bugün ise uzun süreli bir çabanın sonucu olan bütün bu ürünlerin yok edildiğini ortaya koyar. Zamanın önemsiz olduğu zamanların geride kaldığını modern insanın, kısaltılamayacak şeyler üzerinde çaba sarf etmediğini dile döker ve insanoğlunun hikâye anlatıcılığını bile kısaltmayı başardığından söz eder (Benjamin, 2014, s. 85).

Peki, hikâye anlatıc1lığı gerçekten yitip gitti mi yoksa kılıktan kılığa bürünerek hâlâ yaşamaya devam mı ediyor?

\section{Hikâye Anlatıcılığı: Oyun}

Barthes'ın sorusuyla başlayalım: "Anlatıyı neyle değiştirmeli? Anlatı ne 'eder'?” (Barthes, 2016, s. 96) Barthes $S / Z$ 'de "Anlat1, baş döndürücü bir incelikle, kendisini kuran sözleşmenin gösterimidir" (Barthes, 2016, s. 96) der. Ona göre anlatı, anlatıcı ile dinleyici arasında kurulmuş bir sözleşmeye dayanır ve bir değiş tokuş vadeder. Binbir Gece Masalları'nda Şehrazad'ın her öyküsü onun bir gün daha hayatta kalmasını sağlar ve anlatı yaşamın kendisini satın alabilir (Barthes, 2016, s. 95). 
Mikado'nun Çöpleri oyununda da bir kış gecesi bir araya gelen Kadın ve Erkek sabaha kadar birbirine hikâye anlatacaklarına dair bir anlaşma yapar:

ERKEK: Sabahı öyle yapalım. Bir fırsat geçti elimize bu gece. Bir daha birbirimizi görmiyeceğiz ${ }^{1}[$ sic $]$ nasıl olsa... Bir sen anlatırsın, bir ben. Sıra düzen gözetmiyelim. Gelişigüzel... Var mısın? (Kadın başı ile razı olduğunu işaret eder.) Tamam. Ama yargilamak yok. (Anday, 2014, s. 208)

$\mathrm{Bu}$ anlaşma ile kurallar belirlenir ve doğacak hikâyeler ağının mayası atılır. Kadın ve Erkek birbirine hikâye anlatmaya başlar. Sabaha kadar birbirine hikâye anlatan iki kişi gecenin sonunda mavilik açığa çıkarken duvarını yıkar ve yaşamı elde eder. Peki, Kadın ve Erkek birbirine ne anlatır, nasıl anlatır?

Mikado'nun Çöpleri'nde anlatılar oyundan oyuna dönüşerek örülür. Kadın ve Erkek'in başlangıçtaki anlatıcılık oyunu daha sonra bir Uzakdoğu oyunu olan Mikado’ya dönüşür. Kadın ve Erkek bu oyunun kuralları içinde birbirine hikâye anlatmaya devam eder:

ERKEK: (...) Mikado bilir misin?

KADIN: Nedir o?

ERKEK: Bilmiyor musun?

KADIN: Hayır.

ERKEK: Bir oyun. Çok kolaydır. Hadi oynayalım. (...) Yaklaş!

KADIN: Bunlar ne olacak

ERKEK: Çubukları teker teker toplıyacağız. Bir sen, bir ben.

KADIN: Gene sira ile demek

ERKEK: Evet, ama bir çubuğu alırken ötekilerini sarsmayacaksın. (Anday, 2014, s. 230)

Oyunun kuralları yeniden belirlenir ve hikâyeler inşa edilir. Kadın ile Erkek bilinçaltının karanlık koridorlarında dolaşarak karmaşık, tutarsız, düşle gerçek arası öyküler

1 Oyun metninde geçen yazım hataları, oyunun aslında olduğu gibi kullanılmıştır. 
anlatır. Oyunda hikâye anlatma ve dinleme serüveni bir mücadeleye dayanır. Kadın anlatma arzusuyla o geceki hikâyesini ortaya dökmek istedikçe Erkek hikâye dinlemek istemez. Kadın başka bir hikâye erkek başka bir hikâye anlatır. Anlatıcı ile dinleyici iletişim kuramaz:

KADIN: Size biraz kendimden söz etmek istiyordum ben... Gerekli de ondan... İlk görüyorsunuz beni, hem de çok garip bir durumda... Gerçi yormak istemem sizi başımdan geçenlerle...

ERKEK: Öyle bir yemek yiyişi vardı ki, görseniz iğrenirdiniz. Ağzı dolu iken ekmeği ite kaka tıkıyor içeri. Hani farenin kuyruğu kedinin ağzından sarkar ya, bunun da ağzının bir yanından balık kuyruğu sarkıyordu.

KADIN: Öyleleri vardır... Ben anlatmaya hevesli değilim...

ERKEK: Vardır değil, herkes öyle yiyor. Bu yüzden lokantaya gidemiyorum. Eşekler, atlar bizden daha temiz yerler. İçer misiniz? (Anday, 2014, s. 182)

Kadın anlatma çabası karşılıksız kaldığında anlatıyı keser, susar. Dinleyici olmayınca anlatma eylemi anlamsızlaşır. Erkek şöyle der: "Gördünüz mü? İkimizin de aklı başka yerde. Konuşmamız saçma oluyor bu durumda" (Anday, 2014, s. 185).

Erkek dinlemedikçe, ilgisiz kaldıkça Kadın; hikâyesiyle Erkek'in dikkatini çekmeye, onda merak ve korku uyandırmaya çalışır. "Ben kimim?" sorusu ile şaşırtmaca yaratır: “Kötü bir kadın olabilirim, değil mi?” (Anday, 2014, s. 187), "Hırsız olabilirim sözgelişi." (Anday, 2014, s. 187), "Delirmiş olabilirim." (Anday, 2014, s. 187), "Birini öldürmüş olabileceğim de gelmez mi aklınıza?" (Anday, 2014, s. 190), "Peki, sizi öldürebileceğimden korkmuyor musunuz?” (Anday, 2014, s. 190) Kadın, anlatıdaki merak duygusunu artırarak dinleyicisini kışkırtır.

Kadın'ın kim olduğu bir bilmecedir ve oyun boyunca belirsiz kalır: "Kimim ben? Kimsiniz? - Kimlik sorunu, Sfenks'in sorusu, aynı zamanda hem trajik, hem de oyunsal sorundur [.]" (Barthes, 2015, s. 102) Erkek, hikâyelerin içinde Kadın'ın kim olduğunu çözmeye çalışırken kendi kimliğini de çözmeye çabalar. Kadın anlattıkça geçmişi yeniden inşa ederken Erkek de kendi belleğini, hafızasını yeniden üretir. Anlatıdaki belirsizlik, Erkek ve Kadın'ın kimliklerindeki belirsizliği de açık eder. 


\section{Binbir Gece Masallart: Oyun}

Binbir Gece Masalları'nda hikâye anlatmak bir oyundur. Şehrazad, ülkesindeki genç kızların ölümüne son vermek için Şehriyar ile evlenmeye karar verir ve düğün gecesinden evvel bir plan hazırlar:

Bu sırada, Şehrazad, küçük kardeşine yapacaklarını öğretip ona, 'Şahın yanında olduğum sırada seni çağırtacağım; geldiğin ve Şahın benimle işinin bittiğini anladığın zaman, bana: 'Ablacığım, bana o harika öykülerinden birini anlat da geceyi hoşça geçirelim!' de! Bunun üzerine, sana anlatmaya başlayacağım öyküler, eğer Allah isterse, Müslüman kızlarının kurtuluşunun nedeni olacaktır' demiş. (Onaran, 2016, s. 58)

Şehrazad bin bir gece boyunca sabaha kadar hikâye anlatarak Şehriyar'1n öfkesini sağaltır ve ülkesindeki genç kızların hayatını kurtarır. Şehrazad'ın sabaha dek anlattığı öyküler zevk verir:

Anlatının bu noktasında, Şehrazad sabahın belirdiğini görmüş; verilen izinden daha fazla yararlanmadan yavaşça susmuş. Bunun üzerine kız kardeşi Dünyazad, 'Ablacığım, anlattıkların ne kadar tatlı ve zarif ve zevki nasıl okşuyor bilsen!' demiş; Şehrazad, 'Ama bunlar, eğer hükümdarımız beni bağışlar ve hâlâ hayatta olursam, yarın akşam ikinize anlatacaklarımın yanında hiç kalır' diye yanıt vermiş. Şah da kendi kendine, 'Vallahi! Öyküsünün sonunu dinlemeden onu öldürmeyeceğim' demiş.

Sonra Şah Şehriyar ve Şehrazad gecenin geri kalan bölümünü birbirlerinin kollarında geçirmişler (Onaran, 2016, s. 63). Mikado'nun Çöpleri oyununda da Erkek hikâye anlatmakla sevişmek eylemini yan yana getirirken Binbir Gece Masalları'nı yineler ve hikâye anlatıcılığını bir "yazı tura oyununa” dönüştürür. Hikâye anlatıcılığını alaya alır:

ERKEK: Hadi bakalım, kim başlıyacak?

KADIN: Sira sende.

ERKEK: Sevişmiyecek miydik?

KADIN: Hayır, anlatacaktık. 
ERKEK: Önce sevişip sonra mı anlatalım, yoksa önce anlatıp sonra mı sevişelim? (Durur.) Yazı mı tura mı atalım, ha? (Cebinden para çıkarır.) Yazı gelirse sevişeceğiz, tura gelirse... (Kadın'a) Unutma (Parayı havaya atıp avucunun içinde tutar.) Tura. Ne yapacaktık tura çıkarsa?

KADIN: Anlatacaktın. Sira sendeydi.

ERKEK: Peki, sonra sevişiriz. Ama unutturma!" (Anday, 2014, s. 209)

$\mathrm{Bu}$ arzu oyun boyunca tekrar eder. Sabaha kadar hikâye anlatmak cinselliği çağrıştırır. Hikâyeler, dinleyicisini baştan çıkarır. Kadın ve Erkek, sınırlarını çizdikleri oyun alanının içinde, anlatının kurallarını da belirler:

ERKEK: Yazı mı, tura mı atacaktık hani? Sevişmek için

KADIN: Daha sabaha çok var, acele etme. (Anday, 2014, s. 243)

Mikado'nun Çöpleri'nde hikâye anlatma eylemi, ikili bir oyundur ve hem anlatıcısına hem dinleyicisine haz verir. Anlatıcı, hikâyeyi geciktirirken dinleyicisini sabırsızlandırır ve anlatının gideceği yolu uzatır:

Oyun sadece oynama zevki için oynanır, çünkü gidecek başka bir yeri olmayan cinsel dürtülerin yönlendirildiği tek yer bu oyundur. Bunun aynısı, hikâye anlatıcıllğı için de söylenebilir. Hikâyeler, hikâye anlatmanın verdiği zevkten dolay1, ifade edilmediği takdirde ebedî bir bekârete mahkûm edilecek bir arzuyu anlatma isteğiyle anlatılır (Brooks, 2014, s. 111).

Binbir Gece Masalları'nda Şehriyar'ın kardeşi Şahzaman bir yolculuğa çıkar. Dinlenmek için konakladığ 1 yerde sarayda bir şey unuttuğunu hatırlar ve saraya geri döner. Hikâye şöyle devam eder: "dönüp sarayına girmiş. Eşini yataklarında, kölelerinden bir zencinin boynuna sarılmış uyurken bulmuş. Bunu görünce, gözünde dünya kararmış (...) ve kılıcını çekerek ikisini de yatağın örtüsü üzerinde öldürmüsş" (Onaran, 2016, s. 50).

Mikado'nun Çöpleri'nde de hikâye anlatıcısı/Erkek, aynı sahneyi beklenmedik bir sonla gülünçleştirerek yeniden inşa eder:

ERKEK (cıgara verir, yakar): Bir arap filmi görmüștüm. Adam karısını yatak odasında bir erkekle yakalıyor... En dramatik sahne... Siz ne olacak şimdi 
diye merak ede durun, bu manzara karşısında kalan koca, sırtını kapıya yaslıyor, "İşte toplumun yaralarından biri” diyor.

KADIN: Söndü cıgaram.

ERKEK (yakar yeniden): Durun, daha bitmedi... Bunun üzerine kadın, çarşaflara sarılarak yataktan kalkıyor, kocasının yanına geliyor, "Suç benim değil, toplumun" diyor. Sosyal bir oyundu yani. (Anday, 2014, s. 195)

Hikâye anlatma sırası Kadın'a geldiğinde Kadın da anlattığı bir hikâyede Binbir Gece Masalları'nın Alaaddin ve Sihirli Lamba Öyküsü’nü yeniden örer.

Masallar'da Alaaddin'in sihirli lambasına ulaşmak isteyen kurnaz Magripli sepetini yepyeni ve parlak bir düzine bakır lamba ile doldurur. Lambalarla dolu sepeti elinde, sokakları dolaşmaya başlar: "Yeni lambalar! Yeni lambalar! Eski lambalar yenilerini değiştiriyorum! Kim böyle bir değiş tokuşu istiyorsa, gelip yenisini alsın!” (Onaran, 2016, s. 594)Alaaddin'in odasındaki eski lambanın erdemlerinden haberi olmayan Sultan Bedrü’l-Büdur, eski lambayı yenisiyle değiştirir ve Magriplinin tuzağına düşer.

Mikado’nun Çöpleri oyununda Kadın'ın anlattığı hikâye; masalın yapısını söker, masalı sihirli anlamlarından sıyırır ve kaba saba bir şaka malzemesine dönüştürür:

KADIN: Hayır, bak dinle... İlk kocamın çocuğu olmuyordu demiştim ya... Bir eksiklikten değildi, erkekliği yoktu da ondan olmuyordu. Ama bundan ötürü üzülmüyordu hiç. Öyle cakalı idi ki... "Kadından anlarım ben” derdi (...) Bayağıydı da, kaba kaba şakalar yapardı. Sokaktan eskici geçse (Taklit) "Bak, eskiler alayim diyor, vereyim mi seni?" derdi bana. "Vereyim de yenisini alayım, ha?" (Anday, 2014, s. 221-222).

Oyun, Kadın'1 kullanılıp atılmış, eskiciye verilecek bir metaya, bir değiş tokuş nesnesine çevirirken diğer taraftan onu “Alaaddin'in lambası" yerine koyar. Ona sırrı herkes tarafindan çözülemeyecek bir anlam katar. Oyun boyunca Kadın ve Erkek Masallar'ın zamanıyla, öyküleriyle, hileleriyle oynar. Binbir Gece Masalları'nda Şehrazad hikâye anlatmaya günün ilk 1şıklarıyla ara verir:

Anlatısının burasında Şehrazad, sabahın belirdiğini görerek yavaşça susmuş. 
Ama dokuz yüz doksan dokuzuncu gece olunca, demiş ki (Onaran, 2016, s. 733).

Mikado’nun Çöpleri'nde de hikâye anlatma oyununun süresi sabaha kadardır. Kadın ve Erkek sabaha kadar sırayla hikâye anlatır:

KADIN: Sabaha kadar vaktimiz var daha oynayalım.

ERKEK: Oynayalım. (Anday, 2014, s. 235)

Mikado’nun Çöpleri'nde odaya maviliğin dolmasıyla Kadın, etrafa dağılan Mikado'nun çöplerini toplar, Erkek son öyküsünü anlatır ve hikâye anlatma oyunu sona erer:

ERKEK: Bak, bak! Mavilik girmiye başladı orada, görüyor musun?

(İkisi de odaya dolan maviliği seyrederler.)

\section{$(\ldots)$}

Bir dostumuzun evinde sabaha kadar oturmuştuk, sabahleyin ev sahibi bir şişe konyak koydu önümüze, içebilir misiniz dedi. (...) Hiç unutmam, cennet gibi idi dünya. Sonra vurduk karlı sokaklara...

(Kadın ayaklarının ucuna basarak içeriki odaya geçer. Erkek bir süre onun arakasından bakar. Sonra somyeye gider uzanır. Kadın'ın çantasını başının altına koyar. Uyur.) (Anday, 2014, s. 250)

Böylece tüm gece boyunca devam eden hikâye anlatma serüveni biter. Binbir Gece Masalları'nda Şehrazad anlattığı hikâyelerle, karısı tarafından aldatılan Şehriyar'ın öfkesini dindirir, onu sağaltır. Masallar'ın sonunda Şehriyar şöyle der:

Ey Şehrazad, bu öykü ne harika! Oh! Ne kadar hayranlık verici! Ey bilge ve güzel konuşan Şehrazad! Beni eğittin ve benden başkalarının başına gelen olayları gözümde canlandırdın; geçmiş zamanlardaki şahların ve halkların söylediklerini ve başlarından geçen olağandışı ya da harika veya sadece düşünmeye değer şeyleri dikkatle izlettin. Ve gerçekte, şu bin bir gecede seni dinleyerek derinden derine değişmiş ve sevinç ve de yaşam mutluluğuyla dolu bir ruh kazandım. (Onaran, 2016, s. 743)

Geçmişin hafızasında hikâye anlatıcısı hem hekim hem büyücü hem şamandır. 
Hikâye anlatıcısı bilgelik sahibidir, dinleyicisine şifa verir. Peter Brooks hikâye anlatıcısı hakkında şöyle der:

anlatma eylemi sağaltıcı etkisini gösterir; karısının sadakatsizliğinin tetiklediği ve cinayetlere yol açan bir nevroz yaşamakta olan Sultan' 1 iyileştirir (...) ve tehlikeli bir dengesizliğin tehdidi altındaki devleti kurtarır. Şehrazad hikâye anlatmanın hiç de masum bir etkinlik olmadığını ve bir hayatı değiştirebilecek gücü elinde tuttuğunu çok iyi bilmektedir. (Brooks, 2014, s. 90)

Mikado'nun Çöpleri oyununda da Kadın, hikâye anlatmanın hiç de masum bir etkinlik olmadığını çok iyi bilir. Erkek ve Kadın anlattıkça ve dinledikçe iyileşir, kimliklerini yeniden inşa eder. Girdikleri labirentten çıkar. Anlatı; yeni bir yaşam, yeni bir yol, yeni bir son vadeder:

KADIN (Mikado'nun çöplerini toplamıştır, hepsini bir araya getirir, ayağa kalkar, çubukları torbanın içine koyar): Bu iş de bitti. Ben kazandım oyunda değil mi?

ERKEK: Bana sıra gelmedi ki...

KADIN: Bana sıra geldiyse mutlaka sana da gelmiştir. Çünkü bu oyun tek başına oynanmaz. (Adamın yanına gelir.) İkimiz de kazandık. (Anday, 2014, s. 249)

Mikado’nun Çöpleri'nde Erkek ve Kadın hikâye anlattıkça birbirine sı̆̆ınır, kayboldukları boşluktan çıkar ve anlam kazanır. Hafızalarında geri geri giderek yeniden doğar. Anlatı, anlatıcı ve dinleyicinin kabuğu, zırhı, sığınağı olur:

KADIN: Konuşuyoruz, konuştukça sığınacaksın bana.

ERKEK (kahkaha ile güler): Sana mı sı̆̆ınacağım?

KADIN (tiksindiğini gösteren bir yüzle): Evet, benim sana sığındığım gibi. Kabalığın da korkaklıktan.

ERKEK (gülmesi sürer): Sığınacak olsam... Sana sığınmam heralde... (Durur.)

KADIN: Bitir sözünü. Kızmıyorum. Kızmıyacağım artık hiçbir sözüne. 
ERKEK : Nerende korursun beni?

KADIN (sözün sonu nereye varacak diye meraktadır): Anlamadım.

ERKEK : Çantana sokar mısın sözgelişi?

KADIN (çantasına bakar, sonra başını kaldırır): Ben bir defalık bir sığınmadan söz ediyorum. İnsanı değiştirip bırakan bir sığınmadan.

ERKEK: Buradan değişip mi gitmek istiyorsun? (Anday, 2014, s. 234-235)

Kadın ve Erkek hikâyelerin içinde var olmaya, tamamlanmaya çalışır: "Kendimizi var edemediğimiz için yok ediyoruz." (Anday, 2014, s. 245) Var olamama sebeplerini anlattıkça çözüme ulaşır, kendi benlikleriyle yüzleşir. Anlatı, geçmişin izlerini su yüzüne çıkarırken hayalle gerçek arasında dolaşır:

KADIN: (...) Ben hiçbir şey seçmedim bugüne kadar, kendimden hiçbir şey yapmadım, kendim olmadım hiç. (Düş görüyor gibidir.) Ya sokak başında buldum kendimi, ya tanımadığım bir evde. (...) Var olmam başkalarının istemine bağlı kaldı hep. Ama bir defa, yalnız bir defa kendim olmak istedim. Dün akşam istedim bunu. (Anday, 2014, s. 249)

Oyunun sonunda hem Kadın hem Erkek varoluş savaşını kazanır. Mikado'nun Çöpleri'nde hikâye anlatma serüveni aynı zamanda var olma, kimlik kazanma yolculuğudur. Yeniden doğmak için atılan adımdır. Hikâyeler, anlatıcısı ve dinleyicisini erginleştirir, başka bir dünyaya sokar.

\section{Uyumsuz Hikâyeler}

Mikado'nun Çöpleri'nde anlatıların içine rüyalar da karışır. Kadın ve Erkek hafızanın karanlık koridorlarında gezinir. Kadın'ın rüyası, hikâye anlatma-dinleme arzusunu açığa çıkarır. O, belleğinde dolaşarak çocukluğuna varır ve geçmişi yeniden üretir:

KADIN: Bir düş gördüm. Yatağa yatmışım, okul arkadaşlarım çevremi almışlar, hepsi birer hikâye anlatıyordu. Ama ne güzel hikâyeler... Bitmesin istiyordum. Karalar giymiş bir adam da elimden çekip duruyor, "Oldu artık bitti, yürü!” diyor. Arkadaşlarım acıyorlardı bana, "Bitmedi ki..." diyorlardı. Yalvarıyordum o adama, "Daha anlatıyorlar, görmüyor musunuz, hepsi anlatsın, 
sonra gelirim." diyordum. "Boş yere uzatıyorsun" diyordu o adam, "Yürü!" Öyle korktum ki... (Anday, 2014, s. 247-248)

Erkek ise bilinçaltında geçmişin hatıraları arasında kalakalır. Erkeğin rüyası kendi kendine ördüğü labirenti açık eder. Anlatı; modern insanın sıkışmışlığını, çaresizliğini ve ikiliğini ortaya koyar. Oyunda içerisi ile dışarısının karşıtlığı anlatının yapısını söker:

ERKEK: Ben de bir zamanlar bir düş görmüştüm; önümde güzel bir bahçe vardı, koyu yeşil çiçeklere gömülü bir bahçe. Ben sanki bu bahçenin içindeydim, ama bahçeye girecek yolu bir türlü bulamıyordum. Bahçenin içindeyken, bahçenin dışında kalmış olmanın sıkıntısını çekiyordum. Ne sıkıntı, ne sıkınt1... (Anday, 2014, s. 248)

Erkek'in çıkmazı, kapalı kaldığı labirent akla Alaaddin'in öyküsünü getirir. Masallar'da Alaaddin, sihirli lambayı bulmak için yeraltında gizli bir bahçeye girer ve orada mahsur kalır, bahçenin çıkışı olmadığııı gördüğünde ise korkuya kapılır:

Artık ne olursa olsun, 1şık bulunan bahçeye gitmeye, bu karanlık yerlerden kendini kurtararak bir çıkış aramaya karar vermiş. Ama bahçeye açılan kapının önüne gelince, kapalı olduğunu ve artık önünde kendiliğinden açılmadığ1$\mathrm{n} 1$ görmüş. O zaman, korkudan çılgına dönmüş, yeniden mahzenin kapısına koşmuş [.] (Onaran, 2016, s. 531)

Alaaddin masalda yeraltından kurtulmayı başardığında erginleşme yolculuğunu tamamlar, çocukluk günlerini geride bırakır, güç ve ün sahibi olur. Mikado'nun Çöpleri'nde de Erkek hikâye anlatma yolculuğunu bitirdiğinde içinde mahsur kaldığg duvarları yıkar ve karanlıktan çıkar. Peki, bu yolculukta Erkek ne anlatır?

Erkek gece boyunca oyun içinde oyun oynarken birbiriyle uyumsuz parçalardan oluşan hikâyeler anlatır. Hikâye anlatıcılığının kurallarını, gramerini bozar. Anlatıcılık geleneğini söker. Daldan dala atlar, anlamsız sözcükleri bir araya getirir. Absürt bir anlatı inşa eder:

ERKEK: Bir kedimiz vard, ciğerden başka bir şey yemezdi. (...) ciğerden başka yemeklere alıştırmak istedim kediyi. (...) Bir de köpeğimiz vardı, beni ölümden kurtarmıştı. Topal bir köpek... Havuza düssmüştüm. (...) (Seyirciye) Mutluluk nedir diye sorarsanız bana, kaşıntıdır derim. Bir gün az kaldı mutlu oluyordum. Bir sancı saplandı belime, kıvrana kıvrana yatağa düştüm. Böbrek 
taşı imiş. Sancıdan öleceğim. Sabaha karşı idi, doktor geldi morfin yaptı. Derdemez o korkunç sancı kesiliverdi, çok güzel bir dünya başladı birden bire... İnanamıordum... Mutlu idim, tam anlamı ile mutlu... Mutluluğumu doya doya tatmak istiyordum... Ama o ara, kulağımın arkası kaşındı azıcık. Şöyle sinek 1sırmış gibi. Bense kolumu kıpırdatmak istemiyordum, mutluluğuma ara vermemek için. Ama o kaşıntı bozuyordu mutluluğumu. Çaresiz kaldırdım kolumu, kulağımın arkasını kaşıdım, tam olsun mutluluğum diye. Kolumu gene yanıma uzattım. Biraz sonra... Biraz sonra gene o kaşıntı. Kaşıdım, biraz sonra gene. Gene kaşıdım. Bitmedi, bitmedi namussuz kaşıntı, iğneledi durdu ve berbat etti mutluluğumu. (Anday, 2014, s. 246-247)

Anlatı sıçramalarla, şaşırtmacalarla, beklenmedik sonlarla örülür. Erkek hem bir sürü şey anlatır hem de hiçbir şey anlatmaz. Anlattığı hikâyelerle ritüelleri yıkar. Sıradan bir düğün törenini bir Uzakdoğu oyunu olan Mikado’ya dönüştürür ve geleneğin parodisini yapar:

ERKEK: Düğündelermiş... Şimdi dedikoduya başlamışlardır yukarda... Herif hem yıkılır sağa sola, hem de birtakım sululuklar yapar... Bu gece onların işi iş, der gelinle güvey için... Pis pis sırıtır... Bok vardı sanki düğünde? (Taklit) Mutlu bir damat (...) Kutlamak için elini sıkanları hep aynı gülümseme ile karşılar. (...)

Sonra da kutsal aile sözünü dillerinden düşürmezler... (Taklit) Yıkıcılıktır efendim. Ulan sen kendin bir yıkıntısın be! Yok gelenekler varmış, töreler varmış, kutsal kurumlar varmış... Onlar Mikado'nun çöpleri senin için... (Oyunun taklidini yapar) "Dur, ahlak sarsıldı, sıra bende... Bak, geleneği sarsmadan yirmi sayıyı iki parmağımın ucu ile alıvereceğim...”. (Başka bir sesle) "Dur, sarstın geleneği, sıra bende... Şu kutsal kurumlardan birini elime geçirsem işim iştir, ha babam toplarım artık... Oldu bravo!" (Başka bir sesle) "Benim gözüm Samuray'da azizim... çaktırmadan elime geçirdim mi, yaşadım demektir." Oyun oynuyorlar, kumar oynuyorlar be! (Masaya gider, elinin tersi ile Mikado'nun çöplerini darmadağın eder.) (Anday, 2014, s. 239-240)

Erkek geleneği bir oyuna dönüştürürken sistemdeki çarpıklı̆̆1 Mikado oyunu ile anlatır. Geleneği Mikado'nun çöplerini yıktığı gibi yıkar ve yeniden inşa eder. Kadın'ı bir dügündelermiş gibi dansa kaldırır: 
ERKEK: (...) Onlar düğüne giderler de biz gidemez miyiz? Gel, dans edelim seninle... Sayalım ki düğündeyiz... Ben karşıdan seni dansa kaldırmaya geliyorum... Pozunu takın... Hem farkındasın, hem de farkında değilmiş gibi yapacaksın... (Kadın, onun dediği pozu alır. Erkek sahnenin bir ucundan bir dans müziği söyliyerek ve dans ederek Kadın’a yaklaşır.) (Anday, 2014, s. 241)

Anlatı, karşıtlıkları birbirinin içinde eritir. Erkek'in alaylı anlatısı hem dedikoduya karşı çıkar hem de dedikodudan beslenir. Dedikodu anlatının aktığı oluktur, hikâyenin doğum yeridir:

dilimiz dedikodu yapma aracı olarak evrilmiştir ve Homo sapiens her şeyden önce sosyal bir hayvandır, sosyal işbirliği hayatta kalma ve üreme için kritik öneme sahiptir. Kadın ve erkek bireyler için aslanların ve bizonun yerini bilmek yeterli değildir, asıl önemli olan kabilede kimin kimden nefret ettiğini, kimin kiminle ilişkiye girdiğini, kimin dürüst ve kimin hilebaz olduğunu bilmektir. (Harari, 2017, s. 36)

Erkek de etrafinda olan biteni, kimin hilebaz kimin dürüst olduğunu bilir. Dedikodunun ne zaman başlayacağını, kimin ne söyleyeceğini çözer. Hikâye anlatıcılığının en ilkel hali dedikoduyu alaya alır:

Hiç şüphe yok ki anlatı dünya üzerindeki varlığına dedikodu, yani bir kişiden ötekine anlatılan basit hikâyeler biçiminde başladı. Dedikodu, varlığını edebiyatın halk sanatındaki karşılığı, olayları özetlemenin ve anlamlarını araştırmanın kestirme yolu olarak sürdürdü. Hikâye anlatmanın daha ihtişamlı diğer biçimleri gibi, dedikodu da endişelerimizi ve korkularımızı ifade eder[.] (Fulford, 2017, s. 15)

Erkek dedikoduyu alay malzemesine dönüştürerek kutsal sayılan değerlerin kokuşmuşluğunu, çürümüşlüğünü ortaya çıkarır. Her türlü yasanın, kurumun etrafinı sarmış düzenbazları, hilebazları, kurnazları gösterir. Dinleyicisinin beklentisini kırarak onu şaşırtarak anlatının sokaklarını dolaşır. Her türlü otoritenin, iktidarın, devletin kimliksizleştirdiği bireyin hikâyesini anlatır:

ERKEK: (...) Hayyam ne diyor biliyor musun? Ben öyle her gün içmem diyor. Salı, çarşamba, perşembe, cuma, cumartesi, bir de pazar ile pazartesi günleri içerim diyor. 


\section{$(\ldots)$}

ERKEK (ciddileşir, Kadın'ın burnuna kadar sokularak): İçmeyip de bir sürü martaval mı dinliyeyim? (Taklit) Özgürlük dünyası, haklar ve disiplinler rejimi, milli bünye... Kime yutturuyorsun be? Her şey benden gizli olup bitiyor. Ülkenin yönetimi, dünyanın yönetimi... Hepsi benden gizli. Milyonlarca hesaplanan bir yok etme planı içinde ben sadece bir tek sayıyım... Bir ad bile değil... (Anday, 2014, s. 241-242)

Erkek birbiriyle ilgisiz, uyumsuz sözcükleri bir araya getirerek gülünç bir anlatı inşa eder. Her şeyin uyumsuz ve çarpık olduğu bir dünyada dil de sözcükler de oynak bir zemine taşınır. Anlatı, sabit anlamlara ulaşmanın imkânsızlı̆̆ını gösterir. Merkezin yitirilişini imgeler:

ERKEK: Mumya yapmasını bilir misin?

KADIN (uykulu): Anlamadım.

ERKEK (sesini yükselterek): Mumya yapmasını bilir misin diye soruyorum.

KADIN: Ne mumyası?

ERKEK: Misir mumyas1.

KADIN: Hayır.

ERKEK: Lakerda yapmasını?

KADIN (neden sordun): Hayır dedim ya.

ERKEK: İkisi aynıdır. Önce bağırsaklar çıkacak, kan bol su ile temizlenecek. Ondan sonra basacaksin tuzu... (Anday, 2014, s. 246)

Erkek' in birbiriyle uyumsuz anlatıları sistemdeki bozukluğu, dengesizliği, çürümeyi ironik bir şekilde gözümüzün önüne serer. Anlatıda anlam koparılır, alaya alınır, ters yüz edilir. Dildeki karşıtlıklar, anlatıyı parçalar:

okumadan alınan haz, elbette bazı kopmalardan (ya da bazı çarpışmalardan) kaynaklanır: birbirine karşıt kodlar (örneğin soyluyla bayağı) ilişkiye geçer; görkemli ve alaycı yenilikler yaratılır; dilbilgisi kitaplarında örnek olarak kullanıla- 
bilecek kadar pürüzsüz tümcelerin içine pornografik iletiler karışır. Metin kuramında söylendiği gibi: dil yeniden düzenlenir. Ve bu yeniden düzenlenme hep bir kopma aracılığıyla gerçekleşir. İki uç belirir [.] (Barthes, 2016, s. 99)

Erkek hikâye anlattıkça belleğindeki gizli köşeleri aydınlatır. Zihnindeki çelişkiyi, karmaşayı ortaya çıkarır. Geçmişi yeniden inşa ederken sözcüklerin, hikâyelerin uyumunu bozar ve onları yeniden düzenler. Kendi dengesini yaratır.

\section{Hikâye: Bilmece Çözme}

Kadın, Erkek'in anlattığı hikâyeler boyunca iz sürer. Erkek'in kim olduğunu çözmeye çalışır. Hikâyeleri sorgular:

ERKEK: Dinle! (Dolaşmaya başlar, hikâyeyi anlattığı sürece Kadın'a pek az bakar.) İlk okuldayken bir sıra arkadaşım vardı, zayıf, sessiz bir çocuk. Çok çalışkandı, az oynardı. Tek başına dolaşırdı okulun bahçesinde. Gözümün önünden gitmez yüzü... Bir gün bak ne yaptım ona... "Anneni mi daha çok seversin, babanı mı?" diye sordum. Babamı dedi. Oysa babam dediği, babası değildi. Ama çocuk bilmiyordu bunu "Senin baban değil o" dedim sırıta sırıta. (...)

KADIN (ayağa kalkar): Niçin yaptın bunu?

ERKEK: Eğlenmek içindi galiba. Daha doğrusu, niçin olduğunu iyi bilmiyorum. Belki bir bilgi üstünlüğü.

KADIN: Sonra ne oldu?

ERKEK: Çocuk sersemlemiş bir halde gitti, üç gün uğramadı okula.

KADIN: Yalan bu hikâye. Evde annem, babam var diye nasıl yalan söyledinse bunu da öyle uyduruyorsun.

ERKEK (ciddi): Uydurmuyorum.

KADIN: Yemin et uydurmadığına.

ERKEK: Yemin ederim.

KADIN (üstüne yürür adamın): Bana niçin anlatıyorsun? 
ERKEK: Kendi kendime anlatıyorum.

KADIN: Dördüncü gün geldi mi? Çabuk söylesene?

ERKEK (bağırır): Acele etme, anlatıyorum... (Anday, 2014, s. 211-212)

Anlatıc1/Erkek, anlatıcılık sanatındaki hünerini sergiler. Dinleyicisini merak ettirir, bekletir, anlatıyı askiya alır. Dinleyicisini kıvrandırarak "Sonra ne oldu?" sorusunu sordurur: "Aslında, 'sonra ne oldu' sorusunun geçerli olmadığı hiçbir hikâye yoktur” (Benjamin, 2014, s. 92). Dinleyici sabırsızlıkla hikâyenin sonuna ulaşmaya çalışırken anlatıcı da anlatmanın hazzını yaşar. Diğer yandan her anlatı içinde kuşku barındırır. Dinleyici, hikâyenin gerçek olup olmadığını merak eder: "anlatının kendisi, ortaya koyduğu şeyin bir yalan olup olmadığı sorusunu gündeme getirir” (Goody, 2017, s. 149).

Anlatı serüveni boyunca dinleyici bir dedektifin izlediği yolu izler. Hikâyenin altındaki hikâyeyi, hikâyenin gerçek yüzünü araştırır. Kadın ve Erkek'in anlattıkları hikâyelerde hiçbir şey göründüğü gibi değildir. Erkek'in anlattığı hikâye, asıl hikâyeyi gizler. Peter Brooks şöyle der: “'Attention: un récit peut en cacher un autre.' Görünürdeki hikâye başka bir hikâyeyi gizliyor olabilir”’2 (Brooks, 2014, s. 108). Mikado'nun Çöpleri'nde de görünürdeki hikâye asıl hikâyeyi gizler. Kadın bu gizi çözer:

KADIN: Git öteye. (Çubukların üzerine eğilir.) O çocuk, arkadaşın değildi senin.

ERKEK: Hangi çocuk.

KADIN: Illkokuldaki anasız babasız çocuk

ERKEK: Benim anlattığım

KADIN: Evet. (Bir yandan da çubukları almak için uğraşmaktadır.)

ERKEK (sinirli): Kimmiş ya, merak ettim.

KADIN: O kadar merak etme. Sendin.

2 'Fransa'da tren yolu geçitlerinde 'Attention: un récit peut en cacher un autre' (Dikkat: Tren, hemen ardından gelen bir başka treni görmenizi engelleyebilir) ifadesinin yer aldığ tabelalar asılıdır[.]” 


\section{$(\ldots)$}

ERKEK: Öldürdü o çocuk kendini.

KADIN (dikilir): Sen öldürmüşsün onu. (...) büyük duvarlar örmüşün çevrene, ama sonra bir de bakmışın ki duvarların içinde kimse yok. (Anday, 2014, s. 232-233)

Gerçek mi yalan mı olduğu belli olmayan bu hikâyeler dinleyicide merak uyandırır: Erkek hikâyeleriyle geçmişi yeniden inşa eder, kendisine hikâyelerin içinde güvenli bir duvar örer. Hikâye anlattıkça geçmişin derinliklerine gider:

ERKEK: Sıra bendeydi. Dinle! Bir gün dört arkadaş, dördümüzün de Allah belasını versin, sandalla denize çıkmıştık. Üçümüz iyi dosttuk, dördüncü olan aramıza sonradan katılmıştı. Onu kendimizden biraz uzak tutuyorduk. O da bunu anlıyordu, üzülüyordu, kendini sevdirmek için sokuldukça sokuluyordu bize. (...) O gün para çantam kayboldu benim, her yana baktık, sandalın tahtalarını kaldırdık, aradık, aradık, bulamadık.

KADIN: Ne olmuş çantan?

ERKEK: Onun üzerinde kaldı.

KADIN: O arkadaşınızın üzerinde mi?

ERKEK: Evet.

KADIN: Neden başkasının değil de onun?

ERKEK: Çünkü üçümüz iyi arkadaştık, üstelik de o gün biz denizde iken çoğu zaman o kalmıştı sandalda.

KADIN: Belki de o almıştı.

ERKEK: Hayır, eve dönünce buldum para çantamı, yanıma almağı unutmuşum.

KADIN: Söyleseydin gerçeği.

ERKEK: Söylemedim. (Anday, 2014, s. 218-219) 
Erkek'in anlattığı hikâyelerdeki çocuk aslında anlatıcının kendisidir. O, onuru kırılınca kendisini öldüren Samuray'dır. Anlatıcı oyun oynarken de hikâye anlatırken de aslında kendi hikâyesini kurar, bozar. Kendi kendiyle oynar. Kendi kendiyle konuşur: "kendi başımıza konuşur gibi konuşuyoruz" (Anday, 2014, s. 219).

Bilinçaltının koridorları arasında dolaşır. Güçlüyle güçsüzün, ezen ile ezilenin yer değiştirdiği hikâyeler anlatır. Dinleyici de hikâye parçalarını toplaya toplaya anlatıyı çözmeye çalışır:

KADIN: Seni çaldı sanmışlardı arkadaşların. Yalan mı?

ERKEK: Neyi?

KADIN: Anlamazlıktan gelme. Sandaldaki çantayı.

ERKEK (bağırır): Sandılarsa sandılar (...) Bir eğrilik doğruluk dünyası değil bu, denge dünyas1 (Anday, 2014, s. 234).

Mikado'nun Çöpleri'nde anlatıcılar Kadın ve Erkek anlattıkları hikâyelerle oyunun, sistemin, her türlü iktidarın, otoritenin, hiyerarşinin dengesini bozmaya çalışır. Erkek, Mikado'nun çöplerini yıkarak oyunu da, sistemi de, kuralları da altüst eder. Yeni dengeler kurar; normları, geleneği, grameri alaya alır.

\section{Hikâye Örme-Sökme}

Ulrich Marzolph Binbir Gece Masalları'nın gerçek bir "ş̧ekil değiştiren” olduğunu söyler. Masallar, sözlü kültür içinde çeşitli kültürlerden aldıkları eklemelerle dönüşerek günümüze ulaşır (Marzolph, 2010, s. 14). Mikado'nun Çöpleri'nde de hikâyeler tam bir “şekil değiştiren”dir. Kadın ve Erkek'in gece boyunca anlattı̆̆ öyküler bambaşka hikâyelere dönüşür.

Teyzesinin evinden kaçtığı hikâyesiyle anlatısına başlayan Kadın'ın öyküsü kocasının onu evden kovduğu bir öyküye doğru evrilir. Erkek, Kadın'ın anlattığı öykülere inanmaz; hikâyelerin açıklarını, gediklerin ortaya çıkarır:

ERKEK: Hayır, hayır, hayır. Bilmece oynamıyoruz, anlatacaksan anlat. Berbat etme şu güzelim geceyi.

KADIN: Çocuk galiba ilk kocamdan. 
ERKEK (kahkahalarla gülmeye başlar): İlk kocandan mı? Hem de galiba... Demek çocuk daha kundakta iken ikinci kocana vardın. Ortada aldatma falan yok bu durumda.

KADIN: Yok ya.

ERKEK: Öyleyse ilk kocana nafaka davası açsaydın.

KADIN: O da kabul etmiyor çocuğu.

ERKEK: Nasil olur?

KADIN: Ben de anlıyamadım. İlk kocamla evli iken, ikinci kocam olacak adamla seviştim, gebe kaldım. İlk kocamın çocuğu olmuyordu. Gebe kalınca ayrıldım elbet. Öteki ile evlendim. Bu sefer ikinci kocam nedense doktora gidiyor, muayene oluyor, doktor diyor ki, "senin çocuğun olmaz" diyor. (...) Çocuk ilk kocamdan olsaymış kabul edermiş, ama araya üçüncü bir erkeğin karışmış olması deli ediyormuş onu. Ne tuhaf... Kovdu evden beni. Hem de gece yarıs1, kar k1yamette.

ERKEK: Çok güzel bir hikâye! Demek kocanın teyzesinin evinden kaçmadın sen bu gece. Kocan kovdu seni, ha? (Anday, 2014, s. 214).

Kadın'ın anlattığı hikâyeler sonunda anlamsız bir noktaya ulaşır. Her şeyin saçma olduğu bir dünyanın, düzenin anlatıları da anlamsızdır. Erkek ve Kadın anlattıkları hikâyeleri birlikte inşa eder. Hikâyelerin mantık dizgeleriyle oynar. Anlatıyı, anlatıcılığı alaya alır:

KADIN: Gene inanmadın, değil mi?

ERKEK: İnandım ama babasını arıyorum. Her çocuğa bir baba lazım.

KADIN (kendi kendine konuşur gibi): İkisi de sevmiyormuş beni. Çocuk için bir kadın yüzüstü bırakılır mı? (İçer.) Birinden biri benimseyebilirdi çocuğu. (Erkek'e) Peki, ikinci kocam doktora gitmeseydi anlıyacak mıydı sanki? Anlamıyacaktı. Ben de bilmediğime göre geçinip gidecektik. İnsan kızıyor biliyor musun? Ben mecbur muyum çocuğumun babasını bulmaya? (Anday, 2014, s. 214-215) 
Erkek, Kadın'ın anlattığı hikâyeleri bir dedektif gibi sorgular ve hikâyenin devamını merak eder. Hikâyelerin içindeki boşlukları tamamlamaya ve hikâyenin sonuna ulaşmaya çalışır. Kadın'ın hilelerini, tuzaklarını, oyunlarını açık eder:

KADIN: (...) Hadi şimdi sıra sende

ERKEK: Kime yutturuyorsun?

KADIN: Ne yutturmas1?

ERKEK: Bitmedi bu hikâye.

KADIN: Bitti.

ERKEK: Bitmedi diyorum (Anday, 2014, s. 215).

Mikado'nun Çöpleri'nde kadın hikâye anlattıkça önceki hikâyeyi söker başka bir hikâye anlatır, ördüğü ipi her gece söken Penelope'yi hatırlatır:

KADIN: İçerideki çocuk benim çocuğum değil, biliyor musun?

ERKEK: Yarattın... (Bağıra bağıra güler.) Kimin öyleyse, kimin?

KADIN: Çocuklar hepimizin sayılır (Anday, 2014, s. 221).

Kadın, hikâyelerini daha da karmaşıklaştırarak örmeye devam eder. İçerideki çocuğun kendi çocuğu olmadığını onu bir gecekondudan aldıkları öyküsünü uydurur. Bir sonraki hikâyede ise çocuğun gerçekliğini de ortadan kaldırır:

KADIN: İkinci kocam ne bilsin çocuğu dışardan aldığımızı?

ERKEK: Saçmalama. İkinci kocana giderken gebe olduğunu söylemedin mi demin.

KADIN (gözlerini kapar, başını elleri içine alır): Dur, kafam karıştı. Ne dedimdi, ne dedimdi?

ERKEK (bağıırr): Bu çocuk senin doğurduğun çocuk mu, gecekondulardan aldığınız çocuk mu?

KADIN: Hangi çocuk? 
ERKEK: İçerdeki çocuk.

KADIN: Çocuk değil ki o.

ERKEK: Çocuk değil mi?

KADIN: Değil ya... Taş bebek . İnanmazsan git bak! (Anday, 2014, s. 225).

Erkek ve Kadın'ın anlattığı hikâyelerde neyin gerçek neyin yalan olduğu belirsizdir. Karmaşık öyküler ağı okurun anlama karar vermesini engeller. Anlam sürekli değişir, bir sonraki gösterene taşınır. Sonsuz bir döngüde yolculuk eder:

anlam doğrudan göstergede mevcut değildir. Bir göstergenin anlamı, o göstergenin ne olmadığına bağlı olduğuna göre, anlamı da bir bakıma hiçbir zaman kendi içinde taşımaz. Anlam bütün bir gösterenler zincirine dağıtılmış veya yayılmıştır, deyim yerindeyse: Kolayca sabitlenemez, hiçbir zaman tümüyle sadece bir göstergede bulunamaz; fakat sürekli bir mevcudiyet-namevcudiyet kırpışması gibi bir şeydir. Bir metni okumak, kolyedeki boncukları saymaktan ziyade, bu sürekli kırpışma sürecini izlemeye benzer. Anlamı hiçbir zaman sabitleyemememizin, dilin zamansal bir süreç olmasından kaynaklanan başka bir yönü de vardır. Bir cümleyi okurken cümlenin anlamı bir şekilde her zaman askıya alınır, ertelenir veya daha belli değildir, 'gelmekte'dir: Bir gösteren beni bir başkasına, o da bir başkasına götürür durur, ilk anlamlar sonraki anlamlar tarafından dönüştürülür ve cümle bitse de dil sürecinin kendisi bitmez. Her zaman orada olandan daha fazla anlam vardır (Eagleton, 2011, s. 139-140).

Borges, Binbir Gece Masalları hakkında şöyle der: "Öykü içinde öykü insanda tuhaf bir etki uyandırır, neredeyse sonsuz bir etki, baş dönmesi gibi bir şey” (Borges, 2012, s. 57). Mikado'nun Çöpleri de benzer bir baş dönmesi yaratır. Okuru/dinleyiciyi içinden çıkmanın imkânsız olduğu karmakarışık bir labirente sokar:

ERKEK: Saçmalamışız deminden beri.

KADIN (yalvarır gibi):Baştan başlasak, ne dersin, başarabilir miyiz?

ERKEK: Hiç sanmiyorum. 
KADIN: Ben de... Bırak öyleyse, kalsın. Başaramadık. Bilmiyelim. Bilmesek de olur.

ERKEK: Sen değil miydin anlatayım diye çırpınan?

KADIN: Anlattıkça karışıyor. Sana yemin ederim benim hiçbir suçum yok.

ERKEK: Gerçeği saklıyorsun da ondan.

KADIN: Sense basitleştirmek istiyorsun. Görüyorsun ki karma karışık. Ben yapmiyorum.

ERKEK: Büsbütün karışsın öyleyse... Başımızı döndürünceye kadar (Anday, 2014, s. 227).

Kadın ve Erkek hikâyelerin içinde kaybolur. Hikâyeler sarpa sarar, dallanır, budaklanır, yön değiştirir. Hiç bitmeyecekmiş duygusu yaratır.

Masallar' ın adındaki bin sözcüğü sonsuz sayıda geceyi çağrıştırır. Bu sonsuzluk duygusunun şaşırtmacasıyla Araplar, Binbir Gece Masalları'nı hiç kimsenin sonuna dek okuyamadığını söyler (Borges, 2012, s. 54). Mikado'nun Çöpleri de okurda hiç bitmeyecekmiş, sonsuza kadar sürecekmiş hissi uyandırır:

KADIN: Ama ben kendimi öldüremeyince teyzemi öldürdüm. (Gülmeye başlar.)

ERKEK: Atma şimdi... O senin teyzen değildi ki... Demin anlattı̆̆ın kadın... İkinci kocanın teyzesiydi.

KADIN: İnsan yalnız ikinci kocasının teyzesini mi öldürür, kendi teyzesini öldüremez mi?

ERKEK: Sen aklından geçenleri olmuş sanıyorsun. Devam et oyuna (Anday, 2014, s. 236).

Kadın uydurma hikâyeler anlatır, erkek bu hikâyelerden şüphe duyar. Kadın masal uyduran sonra da uydurduğu masalları söküp yeniden ören Penelope'yi; sonsuza kadar masal anlatacak olan Şehrazad'ı andırır. Oyun boyunca gerçek mi yalan mı olduğu belli olmayan hikâyeler anlatmaktan haz duyar: 
ERKEK: (...) sen de bana masal uydurdun burada. Masallar içinde yaşamaktan hoşlanıyorsun çünkü. Kendine boyuna mutsuzluk hikâyeleri uyduruyorsun, bunları gerçek sanmak için de bu geceki gibi sokaklara düşüyorsun. Yoksa senin muhakkak rahat bir evin vardır. Söyle, uydurma değil miydi deminki hikâye?

KADIN: Uydurma olmuş olmamış sana ne? (Anday, 2014, s. 210)

Mikado’nun Çöpleri’nde Kadın'ın kim olduğu bir bilmecedir. Kadın anlattıkça, Erkek onun kim olduğunu çözmeye çalışır. Erkek ve Kadın anlattıkları hikâyeleri birlikte örer, birlikte yeniden inşa eder. Hikâyelerin labirentinde dolaşır, geri gider, başa döner; anlatıyı askıya alır, oyun içinde oyun oynar. Anlatıyı sorgular, anlatıdan şüphe duyar, anlatının hızına kendini kaptırır ve anlatmanın hazzına ulaşır.

\section{Sonuç}

Melih Cevdet Anday'ın Mikado'nun Çöpleri oyununda sırayla anlatılan hikâyeler alayla, ironiyle kesilir. Absürt, anlamsız, karmakarışık bir noktaya ulaşır. Hem anlatılır hem anlatılmaz. Mikado'nun Çöpleri oyununda hikâyeler yön değiştirir, başka kılıklara bürünür, gerçekliğini yitirir, uydurma anlatılara dönüşür. Mikado'nun Çöpleri'nde hikâye anlatıcılığg, gerçeğin ne olduğunu sorgulatır. Kesinlik belirten anlatılara asla ulaşamayacağımızı ortaya koyar.

Mikado'nun Çöpleri oyununda hikâyeler olasılıklara dönüşür, belirsizleşir. Şüpheyi açığa çıkarır. Erkek ve Kadın anlatılan hikâyeleri şüphe ile dinler. Oyun hikâye anlatıcılığı geleneğini yapısöküme uğratır. Anlatma eylemini alaya alır. Hikâyeleri anlamsız, içi boşalmış harflere, sözcüklere dönüştürür. Anlatıcılığın hilelerini, tuzaklarını ortaya çıkarır.

Mikado'nun Çöpleri oyunu bir taraftan hikâye anlatıcılı̆̆ı geleneğini topluma yabancılaşan bireyin hayatında eritirken bir taraftan da bu geleneği devam ettirir. Mikado'nun Çöpleri oyununda yazar, hikâye anlatmanın anlamını sorgular. Hikâye anlatmanın anlatıcı ile dinleyici arasında kurduğu bağa vurgu yapar. Modern insanın bu bağı kopardığını gösterir.

Mikado’nun Çöpleri oyununda hikâyeler kimliği, geçmişi, hafızayı açığa çıkarır. Hikâyeler anlatıcıyı tanımak için birer ipucudur. Oyunda Erkek ve Kadın hikâye anlattıkça birbirini çözer, hikâye anlattıkça iyileşir. Hikâye anlatma aynı zamanda bir inşa süreci- 
dir. Erkek ve Kadın geçmişi hatırlayarak yeniden inşa eder. Ardından inşa ettikleri binay1 y1kar.

Oyunda Erkek ve Kadın'ın anlattığı hikâyeler sosyal yapıyı, düzeni, yönetim sistemini ironize eder. Sistemin çatlaklarını, absürtlüklerini gösterir. Hikâyeler, modern toplum içinde var olmaya çalıştıkça yabancılaşan bireyin çelişkilerini ortaya çıkarır. Her şeyin anlamsız olduğu bir noktaya ulaşır. Her türlü iktidarı, kuralı, geleneği askıya alır.

Oyunda hikâyeleri dinlememe, merakla dinlemeye dönüşür. Anlatıcı, anlatmanın hazzını yaşar. Anlatıyı aniden keser, dinleyicisini bekletir. Onu şaşırtır, korkutur, heyecanlandırır. Mikado'nun Çöpleri oyununda hikâyeler, hikâye anlatmanın hazzından dolayı anlatılır; yalanla, hileyle, alayla örülür ve sonsuza yolculuk eder.

Mikado'nun Çöpleri oyunu bize hikâyelerin olasılıklarını, çatallanan yollarını gösterir. Gerçekle oynar, anlama karar vermemizi engeller. Oyunda Kadın ve Erkek, hikâyeleri birlikte eğirip dokur. Hikâye anlattıkça ve dinledikçe etraflarına ördükleri labirentleri çözer ve yeniden doğar.

\footnotetext{
Hakem Değerlendirmesi: Dış bağımsız.

Çıkar Çatışması: Yazar çıkar çatışması bildirmemiştir.

Finansal Destek: Yazar bu çalışma için finansal destek almadığını beyan etmiştir.

Peer-review: Externally peer-reviewed.

Conflict of Interest: The author has no conflict of interest to declare.

Grant Support: The author declared that this study has received no financial support.
}

\section{Kaynakça/References}

Anday, M. C. (2014). Toplu Oyunlar I: Ölümsüzler. İstanbul: Everest Yayınları.

Barthes, R. (2016). S/Z. (S. Öztürk, Çev.). Kasar. İstanbul: Sel Yayınları.

Barthes, R. (2016). Yazı Üzerine Çeşitlemeler: Metnin Hazzı. (Ş. Demirkol, Çev.). İstanbul: Yapı Kredi Yayınları.

Barthes, R. (2015). Yazı ve Yorum. (T. Yücel, Çev.). İstanbul: Metis Yayınları.

Baudrillard, J. (2001). Baştan Çıkarma Üzerine. (A. Sönmezay, Çev.). İstanbul: Ayrıntı Yayınları.

Benjamin, W. (2014). "Hikâye Anlatıcısı: Nikolay Leskov’un Eserleri Üzerine Düşünceler”. Son Bakışta Aşk. (N. Gürbilek, Haz.). (N. Gürbilek, S. Yücesoy, Çev.). 77-100. İstanbul: Metis Yayınları.

Binbir Gece Masalları: 1/1, (2016). (Â. Ş. Onaran, Çev.). İstanbul:Yapı Kredi Yayınları.

Binbir Gece Masalları: 2/1, (2015). (Â. Ş. Onaran, Çev.). İstanbul:Yapı Kredi Yayınları.

Binbir Gece Masalları: 3/2, (2016). (Â. Ş. Onaran, Çev.). İstanbul:Yapı Kredi Yayınları.

Binbir Gece Masalları: 4/2, (2016). (Â. Ş. Onaran, Çev.). İstanbul:Yapı Kredi Yayınları. 
Borges, J. L. (2012). Yedi Gece. (C. Üster, Çev.). İstanbul: İletişim Yayınları.

Brooks, P. (2014). Psikanaliz ve Hikâye Anlatıcılığı. (H. Demir, Çev.). İstanbul: Boğaziçi Üniversitesi Yayınevi.

Eagleton, T. (2011). Edebiyat Kuramı: Giriş. (T. Birkan, Çev.). İstanbul: Ayrıntı Yayınları.

Fulford, R. (2017). Anlatının Gücü: Kitle Kültürü Çağında Hikâyecilik. (E. Kardelen, Çev.). İstanbul: Kolektif Kitap.

Goody, J. (2017). Mit, Ritüel ve Söz. (D. Sezgi, Çev.). İstanbul: Küre Yayınları.

Harari, Y. N. (2017). Hayvanlardan Tanrllara Sapiens: Insan Türünün Kısa Bir Tarihi. (E. Genç, Çev.). İstanbul: Kolektif Kitap.

Marzolph, U. (2010). “Uluslararası Hikâye Anlatımında Bir Anıt Olarak Binbir Gece Masalları”, Binbir Gece'ye Bakışlar. (M. Kalpaklı, N. D. Sönmez, Haz.). 13-32. İstanbul: Turkuaz Yayınları.

Şklovski, V. (2016). “Öykünün ve Romanın Kuruluşu”, Yazın Kuramı: Rus Biçimcilerinin Metinleri. (T. Todorov, Der.). (M. Rifat, S. Rifat, Çev.). 160-185. İstanbul: Yapı Kredi Yayınları. 
